\title{
Zirconia based nucleic acid sensor for Mycobacterium tuberculosis detection
}

\author{
Maumita Das, ${ }^{1}$ Gajjala Sumana, ${ }^{1}$ R. Nagarajan, ${ }^{2}$ and B. D. Malhotra ${ }^{1,3, a)}$ \\ ${ }^{1}$ Department of Science and Technology Centre on Biomolecular Electronics, National Physical Laboratory, \\ Dr. K. S. Krishnan Marg, New Delhi 110012, India \\ ${ }^{2}$ Department of Chemistry, University of Delhi, Delhi 110007, India \\ ${ }^{3}$ Centre for NanoBioEngineering and Spintronics, Chungnam National University, Daejeon 305-764, \\ Republic of Korea
}

(Received 12 July 2009; accepted 14 December 2009; published online 31 March 2010)

\begin{abstract}
Nanostructured zirconium oxide $\left(\mathrm{ZrO}_{2}\right)$ film (particle size $\sim 35 \mathrm{~nm}$ ), electrochemically deposited onto gold $(\mathrm{Au})$ surface, has been used to immobilize 21-mer oligonucleotide probe (ssDNA) specific to Mycobacterium tuberculosis by utilizing affinity between oxygen atom of phosphoric group and zirconium to fabricate DNA biosensor. This DNA- $\mathrm{ZrO}_{2} / \mathrm{Au}$ bioelectrode, characterized using x-ray diffraction, Fourier transform infrared spectroscopy, cyclic voltammetry, and scanning electron microscopy techniques, can be used for early and rapid diagnosis of $M$. tuberculosis with detection limit of $0.065 \mathrm{ng} / \mu \mathrm{L}$ within 60s. (C) 2010 American Institute of Physics. [doi:10.1063/1.3293447]
\end{abstract}

Tuberculosis is a common infectious disease caused by Mycobacterium tuberculosis. According to World Health Organization report, tuberculosis (TB) is presently the largest cause of death $(\approx 1.6$ millions $)$ from a single infectious agent. Conventional diagnosis of tuberculosis is carried out by polymerase chain reaction, restriction fragment length polymorphism, immunoassays, and southern hybridization technique. However, these diagnostic methods are expensive, time-consuming, laborious, and hazardous. ${ }^{1}$ There is, thus, an urgent need for a sensitive, specific, stable, cost-effective, and reusable method for tuberculosis detection.

Electrochemical DNA biosensors based on nucleic acid hybridization have received considerable attention due to their potential application for diagnosis of various diseases. ${ }^{2,3}$ The immobilization of a biomolecule onto a desired electrode surface is a crucial step for development of a biosensor as it rapidly loses its biological activity in an external environment. In this context, nanocrystalline transparent metal oxides have drawn considerable attention due to their unique physical, chemical, and optical properties that make them promising matrices for sensing applications. ${ }^{4}$

Zirconia $\left(\mathrm{ZrO}_{2}\right)$ is an attractive inorganic metal oxide with thermal stability, chemical inertness, nontoxicity, and affinity for groups containing oxygen that facilitates covalent immobilization without using any cross-linker that may limit sensitivity of the fabricated sensor. It is thus an ideal material for immobilization of biomolecules with oxygen groups. ${ }^{5,6}$ Moreover, it has significantly higher isoelectric point, $\mathrm{pH}$ stability and plays an important role for optical, dielectric, corrosion-resistant coatings, and sensor applications. ${ }^{7} \mathrm{Com}-$ pared to sol gel method, ${ }^{8}$ electrodeposition of $\mathrm{ZrO}_{2}$ offers several advantages like strong adhesion between the deposited film that may be advantageous for biosensor fabrication.

We report results of studies relating to application of electrochemically deposited nanostructured $\mathrm{ZrO}_{2}$ film deposited onto Au surface for fabrication of a DNA biosensor for Mycobacterium tuberculosis detection.

\footnotetext{
a) Author to whom correspondence should be addressed. Electronic mail: bansi.malhotra@gmail.com. Tel.: 91-11-45609152.
}

Zirconium oxychloride $\left(\mathrm{ZrOCl}_{2} .8 \mathrm{H}_{2} \mathrm{O}\right)$, potassium chloride $(\mathrm{KCl})$, oligonucleotide probe sequence specific to $\mathrm{Myco}$ bacterium tuberculosis, complementary target, one-base mismatch and noncomplementary DNA sequences were procured from Lobachemie, Mumbai, India and SigmaAldrich, USA, respectively. All the solutions and glass wares were autoclaved prior to being used and desired reagents (molecular biology grade) were prepared in de-ionized water (Milli Q 10 TS). The sequences of DNA probes used for the electrochemical DNA hybridization detection are as follows:

- Probe: 5'-GGT CTT CGT GGC CGG CGT TCA-3'

- Complementary target:5'-TGA ACG CCG GCC ACG AAG ACC-3'

- One-base mismatch: 5'-TGA-ACG-CCG-ACC-ACGAAG-ACC-3'

- Noncomplementary: $\quad 5^{\prime}$-ATG-TCT-CAA-GCC-AGC -TGC-TG-3'

Zirconia films were deposited onto bare gold electrode in an aqueous electrolyte of $5.0 \mathrm{mmol} \mathrm{L}^{-1} \quad \mathrm{ZrOCl}_{2}$ and $0.1 \mathrm{~mol} \mathrm{~L}^{-1} \mathrm{KCl}$ by cycling the potential between -1.5 to $+0.7 \mathrm{~V}$ (versus $\mathrm{Ag} / \mathrm{AgCl}$ ) at a scan rate of $20 \mathrm{mV} \mathrm{s}^{-1}$ for ten consecutive scans. ${ }^{8,9}$ In the $\mathrm{ZrOCl}_{2} .8 \mathrm{H}_{2} \mathrm{O}$ solution, $\mathrm{ZrOCl}_{2}$ hydrolyzes to tetramer $\left[\mathrm{Zr}_{4}(\mathrm{OH})_{8}\left(\mathrm{H}_{2} \mathrm{O}\right)_{16}\right]^{8+}$ and forms colloidal particles under basic conditions around electrode surface that might have formed from the cathodic reduction of water as indicated by Eqs. (1) and (2):

$$
\begin{aligned}
& 2 \mathrm{H}_{2} \mathrm{O}+2 e^{-} \rightarrow \mathrm{H}_{2}+2 \mathrm{OH}^{-}, \\
& \mathrm{Zr}-\mathrm{OH}+\mathrm{OH}^{-} \rightarrow \mathrm{Zr}-\mathrm{O}^{-}+\mathrm{H}_{2} \mathrm{O} .
\end{aligned}
$$

The electrosynthesis helps in accumulation of the colloidal particles at the electrode surface resulting in formation of the $\mathrm{ZrO}_{2}$ film.

The $\mathrm{ZrO}_{2} / \mathrm{Au}$ surface is washed and subject to $5 \mathrm{~min}$ incubation for attachment of 21-mer oligonucleotide specific to M. tuberculosis (ssDNA, $641 \mathrm{ng} / \mu \mathrm{L}$ ) in a humid chamber at $25{ }^{\circ} \mathrm{C}$. The strong affinity of oxygen of phosphoric group of DNA with zirconia utilized for the immobilization of oligonucleotide on $\mathrm{ZrO}_{2} / \mathrm{Au}$ electrode is likely to result in 


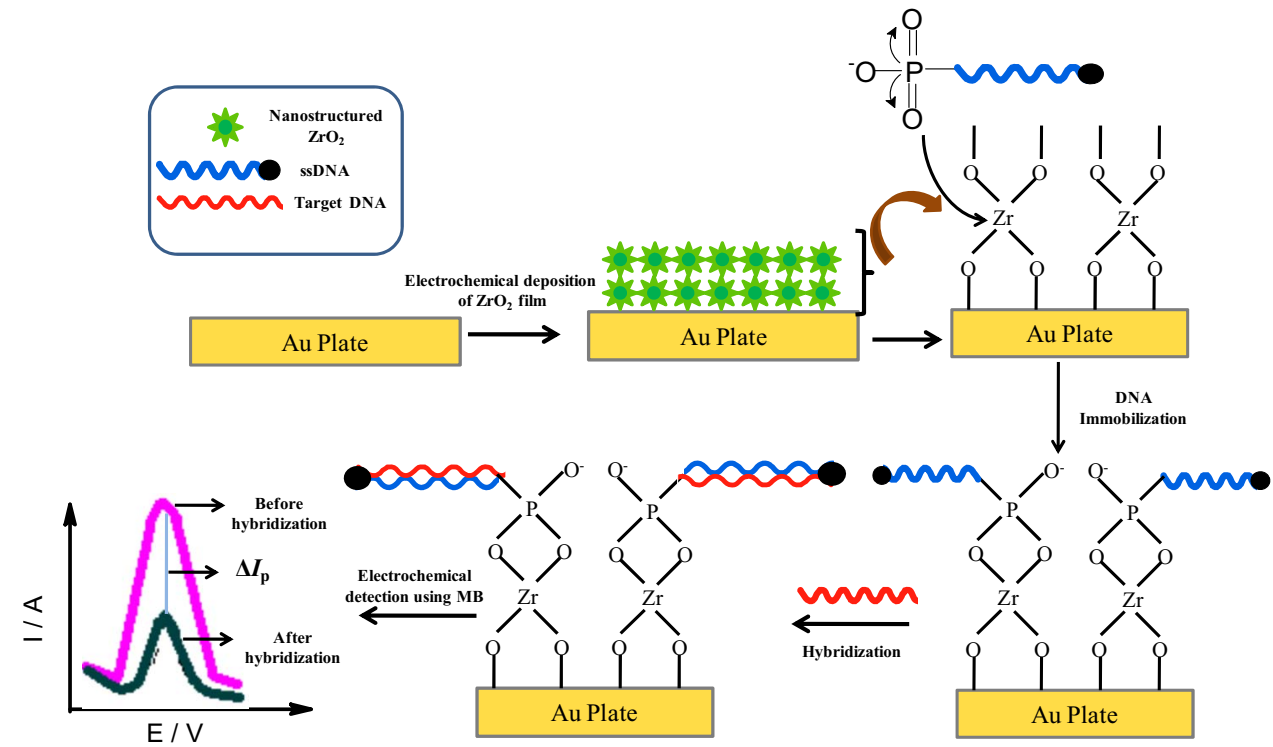

FIG. 1. (Color online) Proposed schematic for the fabrication of nanoZrO $\mathrm{Zr}_{2} / \mathrm{Au}$ based DNA biosensor.

improved sensitivity of the DNA electrode. Figure 1 shows schematic for the fabrication of $\mathrm{NanoZrO}_{2} / \mathrm{Au}$ based DNA bioelectrode.

The prepared ssDNA- $\mathrm{ZrO}_{2} / \mathrm{Au}$ bioelectrode was stored at $4{ }^{\circ} \mathrm{C}$ when not in use. ssDNA- $\mathrm{ZrO}_{2} / \mathrm{Au}$ electrode was characterized using XRD (Rigaku Miniflex II Desktop), Fourier transform infrared spectroscopy (PerkinElmer, Spectrum BX II), scanning electron microscopy (LEO 440). Electrochemical data was obtained by an Autolab Potentiostat/ Galvanostat (Eco Chemie, Netherlands) using a threeelectrode system with $\mathrm{Au}$ as working electrode, platinum wire as auxiliary electrode, and $\mathrm{Ag} / \mathrm{AgCl}$ as reference electrode in PBS solution containing $5-\mathrm{mM}\left[\mathrm{Fe}(\mathrm{CN})_{6}\right]^{3-/ 4-}$. The ssDNA-Z $\mathrm{ZrO}_{2} / \mathrm{Au}$ electrode was optimized for hybridization time and was subject to incubation in desired concentration (641-0.0641 ng/ $\mu \mathrm{L}$ ) of complementary target solution for $60 \mathrm{~s}$ at $25^{\circ} \mathrm{C}$. Subsequently, CV and DPV measurements of ssDNA-Z $\mathrm{ZrO}_{2} / \mathrm{Au}$ electrode were carried out in presence of $10-\mu \mathrm{M}$ methylene blue (MB), in $0.05 \mathrm{M}$ phosphate buffer pH 7.0 containing $0.9 \% \mathrm{NaCl}$.

XRD studies of $\mathrm{ZrO}_{2} / \mathrm{Au}$ show a high degree of preferential orientation giving rise to the spectra resembling single crystal diffraction pattern. ${ }^{11}$ The prepared $\mathrm{ZrO}_{2}$ film shows (211), (032), (330), and (210) diffraction planes corresponding to crystalline $\mathrm{ZrO}_{2}$ structure and well-matches with the standard (JCPDS No. 371484) data having cell parameters as $a=5.312, b=5.212$, and $c=5.147 \AA$. The average crystallite size of the $\mathrm{ZrO}_{2}$ calculated using DebyeScherrer equation is found to be $\sim 35 \mathrm{~nm}$.

FT-IR spectra of $\mathrm{ZrO}_{2} / \mathrm{Au}$ exhibits characteristic peaks at 544 and $668 \mathrm{~cm}^{-1}$ arising due to the symmetric stretching of $\mathrm{Zr}-\mathrm{O}-\mathrm{Zr}$ species indicates the zirconia film formation onto the gold surface. ${ }^{7,9}$ The bands observed at about 1497 , $1547,1648 \mathrm{~cm}^{-1}$ are due to $\mathrm{Zr}-\mathrm{O}-\mathrm{C}$ vibrations. ${ }^{11}$ The IR spectrum of DNA- $\mathrm{ZrO}_{2} / \mathrm{Au}$ is recorded with $\mathrm{ZrO}_{2} / \mathrm{Au}$ as the reference. Peaks seen at 1024 and $1546 \mathrm{~cm}^{-1}$ are due to $\mathrm{P}-\mathrm{O}$ and $\mathrm{C}-\mathrm{O}$ stretching vibrations of $\mathrm{PO}_{4}$ backbone and purine and pyrimidine rings of DNA, respectively. The $1653 \mathrm{~cm}^{-1}$ band arising due to vibrational band of $\mathrm{Zr}-\mathrm{O}-\mathrm{P}$ overlaps with the amide bond. ${ }^{11}$
The results of SEM studies carried out on $\mathrm{ZrO}_{2} / \mathrm{Au}$ and DNA- $\mathrm{ZrO}_{2} / \mathrm{Au}$ electrode show uniform distribution of zirconium oxide nanoparticles with regular and patterned morphology. The aligned surface structure of DNA- $\mathrm{ZrO}_{2} / \mathrm{Au}$ electrode is assigned to the uniform binding between $\mathrm{PO}_{4}^{-}$ backbone of DNA and $\mathrm{ZrO}_{2}$ and uniform structural morphology of $\mathrm{ZrO}_{2}$ film. ${ }^{11}$

Cyclic voltammetric studies (CV) were carried out on (a) bare Au; (b) $\mathrm{ZrO}_{2} / \mathrm{Au}$ film; and (c) $\mathrm{DNA}-\mathrm{ZrO}_{2} / \mathrm{Au}$ bioelectrode. The peak current ratio $\left[I_{\mathrm{Pa}} / I_{\mathrm{pc}}\right]$, calculated from Eq. (3), decreases in the order: Bare gold(1.756) $>\mathrm{ZrO}_{2} / \mathrm{Au}(1.557)>\mathrm{DNA}-\mathrm{ZrO}_{2} / \mathrm{Au}(1.543) .{ }^{11}$

$$
\left|\frac{I_{\mathrm{pa}}}{I_{\mathrm{pc}}}\right|=\frac{I_{\mathrm{pa}}}{I_{\mathrm{pc}}}+0.485 \frac{I_{\lambda}}{I_{\mathrm{pc}}}+0.086 .
$$

The CV studies of DNA- $\mathrm{ZrO}_{2} / \mathrm{Au}$ bioelectrode conducted as a function of scan rate $(50-300 \mathrm{mV} / \mathrm{s})$ reveal that peak-topeak separation potential increases with increasing scan rate indicating uniform facile charge transfer kinetics and follows $\Delta E(\mathrm{~V})\left(\mathrm{DNA}-\mathrm{ZrO}_{2} / \mathrm{Au}\right)=0.32 \mathrm{~V}+6.43 \times 10^{-4}$

$\times$ Scan $r a t e(m V / s)$ with $r=0.954 .{ }^{11}$ The surface concentration of ionic species per unit area $(\Gamma)$ calculated using Laviron's theory ${ }^{10}$ has been found to be $3.46 * 10^{-6}$ and $7.91 * 10^{-6}$ moles $/ \mathrm{m}^{2}$ for $\mathrm{ZrO}_{2} / \mathrm{Au}$ and DNA- $\mathrm{ZrO}_{2} / \mathrm{Au}$, respectively. The increased value of $\Gamma$ for $\mathrm{DNA}-\mathrm{ZrO}_{2} / \mathrm{Au}$ indicates immobilization of electroactive DNA molecules on the electrode surface. ${ }^{11}$

Figure 2 shows results of electrochemical response measurements of DNA- $\mathrm{ZrO}_{2} / \mathrm{Au}$ electrode carried out as a function of target DNA concentration using $\mathrm{MB}$ as indicator in phosphate buffer $(50 \mathrm{mM}, \mathrm{pH} 7.0,0.9 \% \mathrm{NaCl})$. A significant decrease in the magnitude of $\mathrm{MB}$ signal is observed when incubated with complementary target sequence and is attributed to the steric and conformational changes induced during hybridization process. It is found that MB peak height increases with decrease in the complementary target concentration from 641 to $0.065 \mathrm{ng} / \mu \mathrm{L}$, revealing $0.065 \mathrm{ng} / \mu \mathrm{L}$ as the detection limit. The decrease in the MB peak height with increase in complementary DNA concentration may be attributed to the hindrance provided to MB-Guanine interac- 


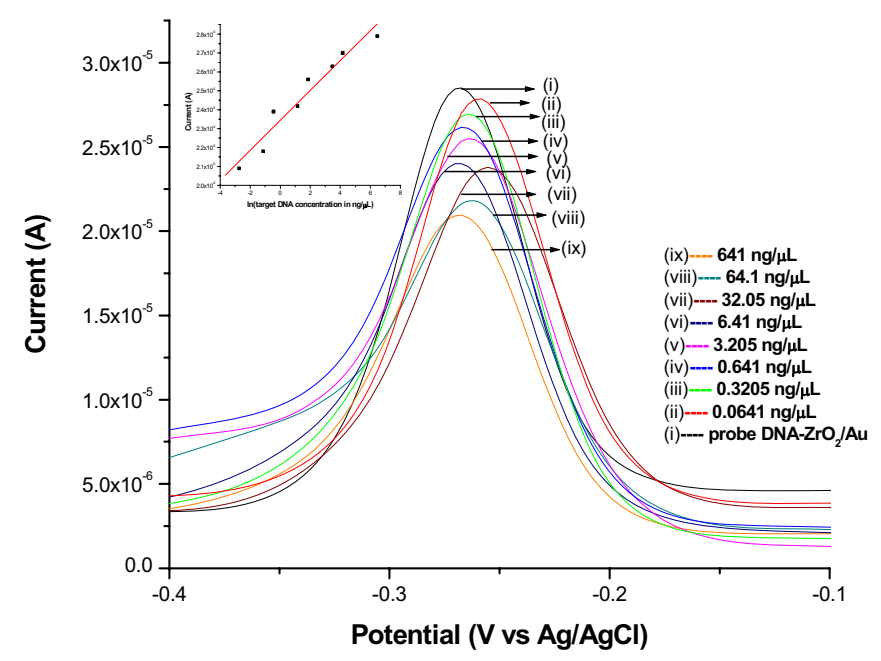

FIG. 2. (Color online) (Color online) Differential pulse voltammograms of ssDNA- $\mathrm{ZrO}_{2} / \mathrm{Au}$ bioelectrode after hybridization with complementary sequence in $0.05 \mathrm{M}$ phosphate buffer of $\mathrm{pH} 7.0$ containing $0.9 \% \mathrm{NaCl}$ and methylene blue (MB, $10 \mu \mathrm{M})$. [Inset shows the MB peak height as a function of $\ln$ (target DNA concentration)].

tions due to increased double stranded DNA formation. No further decrease in $\mathrm{MB}$ signal above $641 \mathrm{ng} / \mu \mathrm{L}$ reveals that all the hybridization sites on the $\mathrm{DNA}-\mathrm{ZrO}_{2} / \mathrm{Au}$ electrode are covered. The anodic peak current of $\mathrm{MB}$ varies linearly with the logarithm of the complementary target concentration [Eq. (4)]:

$$
\begin{aligned}
I_{d M T}= & 7.90 \times 10^{-7}[\ln (\text { target DNA-conc in } \mathrm{ng} / \mu \mathrm{L})]+2.34 \\
& \times 10^{-5}
\end{aligned}
$$

with regression coefficient (r) as 0.972

Figure 3 exhibits results of DPV studies of DNA- $\mathrm{ZrO}_{2} / \mathrm{Au}$ bioelectrode on hybridization with Genomic DNA of Mycobacterium tuberculosis. With increasing Genomic DNA concentration $(1-150 \mathrm{ng} / \mu \mathrm{L})$, MB oxidation current $\left(I_{\text {genomic }}\right)$ decreases, indicating increased number of DNA duplexes formed at the $\mathrm{ZrO}_{2}$ surface [Eq. (5)]. The lower detection limit of ss-DNA/ $/ \mathrm{rO}_{2} / \mathrm{Au}$ electrode with genomic DNA is found to be $1 \mathrm{ng} / \mu \mathrm{L}$

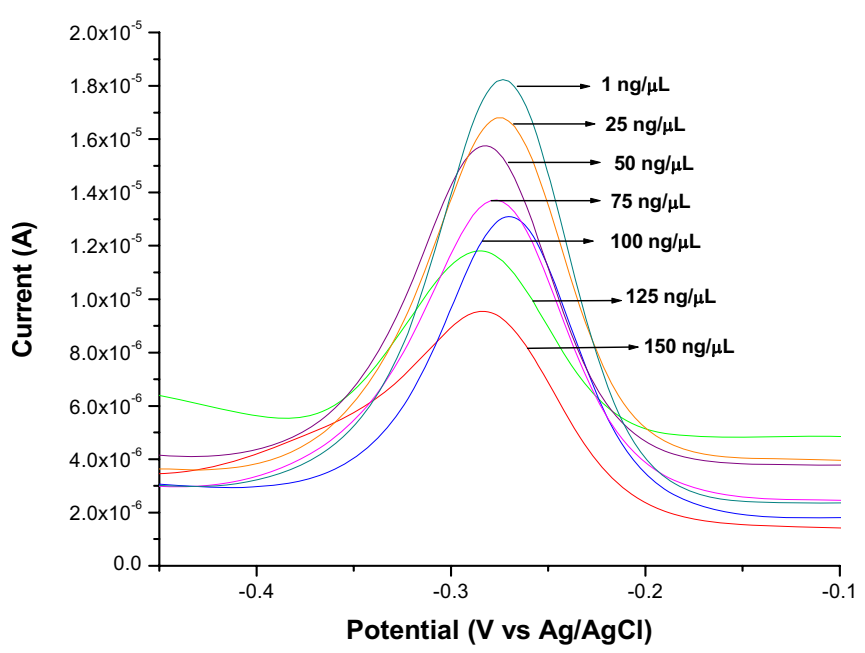

FIG. 3. (Color online) Differential pulse voltammograms of ssDNA- $\mathrm{ZrO}_{2} / \mathrm{Au}$ bioelectrode after hybridization with $M$. tuberculosis genomic in $0.05 \mathrm{M}$ phosphate buffer of $\mathrm{pH} 7.0$ containing $0.9 \% \mathrm{NaCl}$ and methylene blue (MB, $10 \mu \mathrm{M})$.

$$
\begin{aligned}
I_{\text {genomic }}= & -1.425 \times 10^{-6}[\ln (\text { conc of genomic DNA in } \mathrm{ng} / \mu \mathrm{L})] \\
& +1.94 \times 10^{-5} .
\end{aligned}
$$

The selectivity of the DNA- $\mathrm{ZrO}_{2} / \mathrm{Au}$ electrode has been investigated by monitoring change in methylene blue oxidation current by incubating it with complementary oligonucleotide sequence, noncomplementary oligonucleotide sequence and one-base mismatch. ${ }^{11}$ The highest MB signal is obtained with the probe DNA because $\mathrm{MB}$ has a strong affinity for the free guanine bases and hence maximum accumulation of $\mathrm{MB}$ occurs at this surface. The peak current value does not significantly decrease when the ssDNA- $\mathrm{ZrO}_{2} / \mathrm{Au}$ electrode is exposed to the noncomplementary oligonucleotide in the control experiments, indicating that no change occurs at the electrode surface revealing selectivity of the bioelectrode for hybridization detection. The improved sensitivity $\left(7.9 \times 10^{-7} \mu \mathrm{L} / \mathrm{ng}\right)$, reusability $\left(10-12\right.$ times) and stability (about 4 months) ${ }^{11}$ of DNA-Z $\mathrm{Zr}_{2} / \mathrm{Au}$ bioelectrode has been attributed to the affinity between oxygen atom of phosphate group of DNA and zirconia linked to gold surface.

A cost-effective biosensor has been fabricated by immobilizing probe DNA specific to M. tuberculosis on electrochemically deposited nanostructured $\mathrm{ZrO}_{2}$ film (crystallite size $\sim 35 \mathrm{~nm})$ without use of any cross-linker. The DNA- $-\mathrm{rO}_{2} / \mathrm{Au}$ is found to have linearity from 640 to $0.065 \mathrm{ng} / \mu \mathrm{L}$, response time as $60 \mathrm{~s}$, stability as four months when stored at $4{ }^{\circ} \mathrm{C}$ and detection limit of $0.065 \mathrm{ng} / \mu \mathrm{L}$ of target DNA concentration and of genomic DNA as low as $1 \mathrm{ng} / \mu \mathrm{L}$ indicating that it can be used for rapid and early detection of M. tuberculosis. ${ }^{11}$ The stability of DNA bioelectrode is attributed to the conducive environment provided by biocompatible $\mathrm{ZrO}_{2}$. Efforts should be made to utilize this bioelectrode with clinical samples and to fabricate DNA sensors for detection of pneumonia and cholera etc.

We thank Professsor R. C. Budhani, Director, National Physical Laboratory, India for facilities. M.D. thanks CSIR, India for award of a Senior Research Fellowship. We thank Dr Y. Singh, Institute of Genomics and Integrative Biology, India for providing $M$. tuberculosis genomic DNA. Financial support received from DST, DBT, CSIR, India is gratefully acknowledged.

${ }^{1}$ N. Prabhakar, K. Arora, S. K. Arya, P. R. Solanki, M. Iwamoto, H. Singh, and B. D. Malhotra, Analyst (Cambridge, U.K.) 133, 1587 (2008).

${ }^{2}$ K. Arora, N. Prabhakar, S. Chand, and B. D. Malhotra, Anal. Chem. 79, 6152 (2007).

${ }^{3}$ N. Prabhakar, H. Singh, and B. D. Malhotra, Electrochem. Commun. 10, 821 (2008).

${ }^{4}$ S.-Q. Liu, J.-J. Xu, and H.-Y. Chen, Bioelectrochemistry 57, 149 (2002).

${ }^{5}$ R. Shacham, D. Mandler, and D. Avnir, Chemistry 10, 1936 (2004).

${ }^{6}$ Y. Gao, Y. Masuda, H. Ohta, and K. Koumoto, Chem. Mater. 16, 2615 (2004).

${ }^{7}$ Z. Tong, R. Yuan, Y. Chai, Y. Xie, and S. Chen, J. Biotechnol. 128, 567 (2007).

${ }^{8}$ S. Q. Liu, Z. H. Dai, H. Y. Chen, and H. X. Ju, Biosens. Bioelectron. 19, 963 (2004b)

${ }^{9}$ J.-M. Lin, H. Ming-chi, and K.-Z. Fung, J. Power Sources 159, 49 (2006).

${ }^{10}$ H. Ma, L. Zhang, and Y. Pan, K. Zhang, and Y. Zhang, Electroanalysis 20, 1220 (2008).

${ }^{11}$ See supplementary material at http://dx.doi.org/10.1063/1.3293447 for results of XRD, FT-IR, SEM, CV, DPV studies and Table 1. 